\title{
Teachers' Attitude towards Minimum Competency Assessment at Sultan Agung Senior High School in Pematangsiantar, Indonesia
}

\author{
Herman $^{1}$, Afifa May Shara ${ }^{1}$, Tiodora Fermiska Silalahi ${ }^{2}$, Sherly $^{3,{ }^{*}} \&$ Julyanthry $^{3}$ \\ ${ }^{1}$ English Education Department, Universitas HKBP Nommensen, Medan, Indonesia \\ ${ }^{2}$ English Education Department, Universitas Simalungun, Pematangsiantar, Indonesia \\ ${ }^{3}$ Sekolah Tinggi Ilmu Ekonomi Sultan Agung, Pematangsiantar, Indonesia \\ *Corresponding author: Sekolah Tinggi Ilmu Ekonomi Sultan Agung, Pematangsiantar, Indonesia. E-mail: \\ sherlychi12345@gmail.com
}

Received: September 27, 2021

Accepted: November 24, 2021 Online Published: January 18, 2022

doi:10.5430/jct.v11n2p1

URL: https://doi.org/10.5430/jct.v11n2p1

\begin{abstract}
In order to replace all students in Indonesia, the minimum competency assessment is administered in 2021 . The evaluation includes literacy, literacy and financial literacy. This study seeks to examine the attitude of teachers to the minimum assessment of competence or known as the minimum competence assessment (AKM). A descriptive qualitative method with a statistical method was used in this research. There were 34 teachers at Sultan Agung Senior High School in Pematangsiantar, Indonesia (SMA Sultan Agung). The participants therefore received questionnaires. Questionnaire statements distributed through Google form. The delivery of questionnaires via Google's Covid-19 form, which prevented the scientist from conducting face-to-face research with its participants. There were 12 items on the questionnaire given. There are 4 question items for each component. Overall, the results of the teachers' research attitudes towards the assessment of minimum skills achieved a maximum score of 60 and a minimum score of 12. After the data are analyzed, more teachers agree that in the implementation of the AKM they are looking for the issues themselves. There were 18 teachers $(48.6 \%)$ in the group who agreed on the statement, which was a sharp contrast to those teachers who disagreed, i.e. (2.7 percent). The teachers therefore really want to know about AKM. With numerous references to AKM on the Internet, it helps teachers to practice AKM.
\end{abstract}

Keywords: assessment administration, attitude, evaluation, AKM, teacher

\section{Introduction}

Education in Indonesia has begun to head towards a better direction, the application of literacy in Indonesia is increasingly emphasized. It was demonstrated through the Minister of Education's decision to replace National Examination into Minimum Competency Assessment which will begin in 2021. Minimum Competency Assessment is one of four "Freedom of Learning" programs issued by the Ministry of Education and Culture. Minimum Competency Assessment will be held in the middle of the education level, grade 5 for elementary school, grade 8 for junior high school and grade 11 for senior high school, this is done not without reason, Minimum Competency Assessment is expected to encourage teachers and schools to improve the quality of learning and cannot be used as a basis for student selection to the next level. Minimum Competency Assessment consisted of literacy (reading and writing) and numeracy adapted from PISA test. Reading literacy and numeracy are the basic competencies that are tested and become benchmarks in the implementation of the Minimum Competency Assessment (Kisno, Siregar, Sirait, \& Winata, 2021). Reading and writing literacy is one of the basic literacy that must be mastered before mastering other types of literacy (Shara, Andriani, Ningsih, \& Shinoda, 2020). By having the ability to read and write, someone will be better in living his life. To pass the Minimum Competency Assessment students are required to master these literacies so that they are able to think critically in this era (Ningsih, Shara, \& Andriani, 2021).

The ability of students in Indonesia to compete internationally is very doubtful. Based on the results of the PISA test in 2018 , Indonesia is still in the bottom 10 position. This can be seen from the Figure 1 below. 


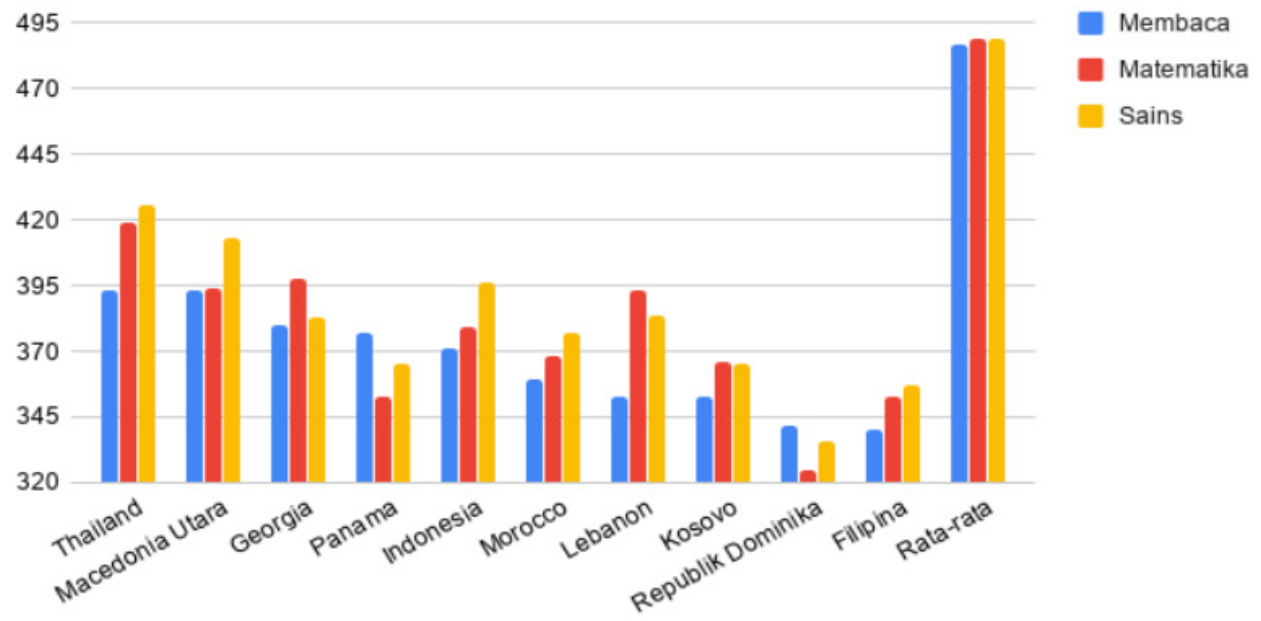

Figure 1. Indonesian Pisa Test Results in 2018

Source: Dewabrata (2019).

The bar Figure above gives us information about Indonesia's position as the bottom 10 of the PISA test results in 2018 in points. Overall it can be seen that the ability of Indonesian students in reading, mathematics and science literacy is still far below average. From the diagram also shows that Indonesia is included in the three Southeast Asian countries which occupy the bottom 10 of the PISA test. The bar Figure gives us information about the highest points obtained by Indonesia, which is 395 points through science literacy. It succeeded in bringing Indonesia ranked $74^{\text {th }}$ out of 79 countries.

The ability of Indonesian students to compete in international tests is still very low, especially in reading literacy which is always decreasing. Indonesian students always seem to have a harder time answering reading literacy questions than the other two literacies, mathematic s and science literacy. The points gained by Indonesia through reading literacy on the PISA test are always disappointing and below standard. This can be seen from the Figure 2 below.

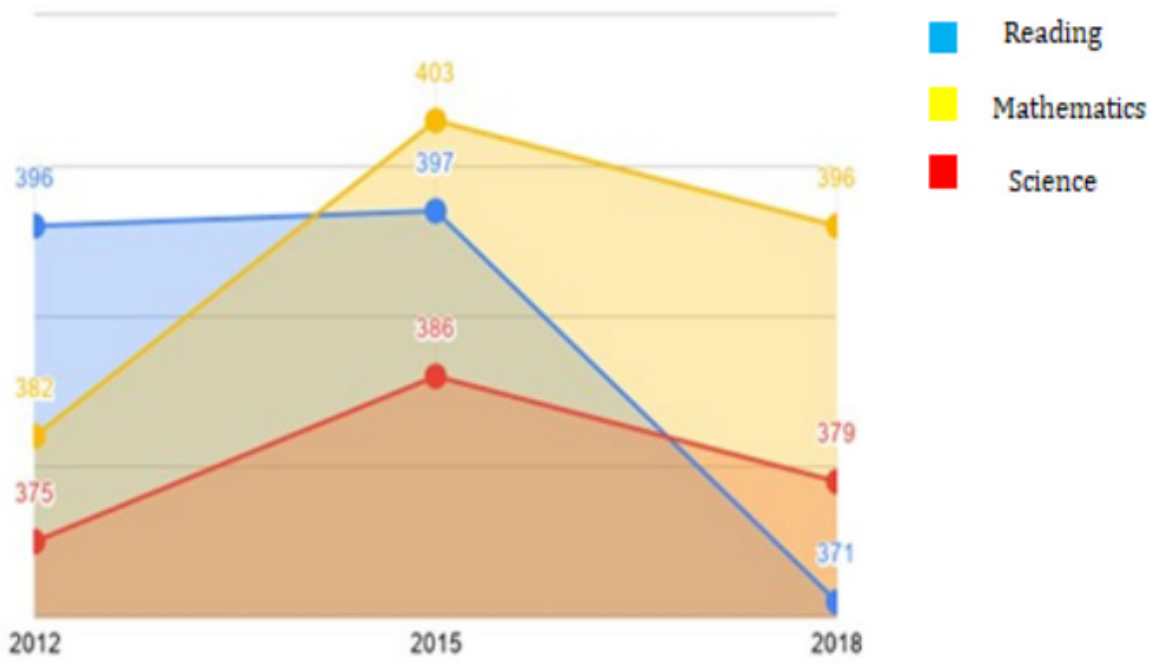

Figure 2. Reading Literacy and Numeracy Scores of Indonesia

Source: Dewabrata (2019).

The line graphs above give us information about the comparison in the number of points of reading literacy, mathematics literacy and science literacy that Indonesia obtained in the PISA test from 2012 to 2018. Overall it can be seen that some fluctuation occurred, but the points obtained by Indonesia in all of the literacies fell down in the final period. The line diagram also shows the points that Indonesia gained through reading literacy. In 2012, literacy 
reading got the highest score from the other two literacies and remained stable until 2015, but in 2018 reading literacy has decreased to become the lowest point of literacy compared to the other two literacies. This shows that reading literacy is the most difficult literacy according to Indonesian students.

Currently, students' literacy skills are still very low, this can be seen from the ability of students to answer literacy questions on the PISA test. PISA helps governments to not only understand, but also to enhance, the effectiveness of their educational systems and to learn from other countries' practices (Thomson, 2013). On the PISA test, students' literacy skills in Indonesia are still low. This is evidenced by the results of the 2018 PISA test where Indonesia only had to be satisfied with the bottom 10 of the 79 countries that took the pisa test. The results of the 2018 pisa have indeed decreased when compared to the results obtained by Indonesia in 2015 and 2012. Since 2012, Indonesia's literacy reading score has always decreased. In fact, reading literacy is one of the keys to literacy in order to master other literacy. The PISA scores for 2012 to 2018 are 396,397 and 371. In literacy reading skills in Indonesia, it is very difficult for Indonesia to get a score of 400 . This is one of the factors that makes Indonesia get low ranking test results. As an initial form of improving the education system in Indonesia, the Indonesian government has set a target PISA score that Indonesian students must obtain. In the field of reading literacy, the government is targeting a score of 396 in 2020-2025, a score of 423 in 2025-2030 and 451 in 2030-2035. By looking at the government's target, we can see that at least for the next 15 years, Indonesia's highest PISA score target is far below the average PISA score of OECD countries. This means that it is very difficult for Indonesia to be able to get results or scores above the average in the next 5 PISA tests and to have good literacy skills.

The National Assessment is an effort to take pictures comprehensive quality of process and learning outcomes of basics education units (Perdana, 2021). The National Assessment which will be held in 2021 is not only attended by students, but teachers to school principals also take part in the national assessment in each education unit. Information from students, teachers and school principals is expected to provide complete information about the quality of the process and learning outcomes in each education unit. With this information, it can make it easier for the government to evaluate education. National Assessment is also used to capture the impact of the learning process in each educational unit. as we know the teacher is a central point in education. Teachers do not only function as teachers and as facilitators who can provide convenience and train students to be more active in the learning process. For this reason, the existence of this Minimum Competency Assessment can also be a reflection for teachers that in the learning process they must develop the full potential of students both cognitively and non-cognitively. In the National Assessment all teachers must follow it, because the target respondents for the National Assessment are all teachers, both permanent employment status and honorarium employees whose purpose is to gather information that reflects the real conditions of the school. For that, teachers must also have knowledge capital to be able to face Minimum Competency Assessment this year.

The Ministry of Education and Culture officially launched the "Teacher Learning Series for Minimum Competency Assessment (Guru Belajar Seri Asesmen Kompetensi Minimum (AKM)" in 2020. This series are very useful for teachers who may still have many teachers who have wrong or insufficient knowledge in dealing with Minimum Competency Assessment. These activities aim to: (1) understand the concept of the National Assessment. (2) Understand the form of the implementation of the National Assessment. (3) Analyze examples of reading literacy assessments in the Minimum Competency Assessment. (4) Analyze examples of numeration assessments on the Minimum Competency Assessment. (5) Read and follow up the report on the results of the Minimum Competency Assessment. (6) Doing pengimbasi by inviting other fellow teachers to take part in the Teacher Learning program and Sharing Minimum Competency Assessment series (https://www.kemdikbud.go.id/main/). Teacher learning materials for Minimum Competency Assessment can be accessed through the official website of the Ministry of Education and Culture https://gurubelajar-akm.simpkb.id/. The program is designed to assist teachers and principals in each educational unit in understanding the objectives, concepts and forms of implementation of the National Assessment and can analyze examples and be able to analyze examples of literacy and numeracy in the Minimum Competency Assessment. This program is certainly very useful because fellow teachers can learn and can work together in completing the program stages.

To be able to face Minimum Competency Assessment well, it is necessary to have a good attitude. So a research on teachers' attitudes towards Minimum Competency Assessment is needed. This is because teachers will also be involved in the implementation of the akm which will be held this year. Most of the teachers have understood Minimum Competency Assessment, but there are still teachers who do not understand Minimum Competency Assessment. Even though all teachers should have more understanding about that. So, what is the teachers' attitude towards Minimum Competency Assessment? Looking at the existing problems, the purpose of this study is to find out the teachers' attitudes towards Minimum Competency Assessment in 2021. 


\section{Review of Literature}

\subsection{Attitude}

Attitude in the narrow sense is a mental outlook or tendency. Attitude is a tendency to react to something, person or thing. Thus, in principle, we can think of that attitude as a tendency for students and others to act in certain ways. Allport (1935) defines a mental and neural state of readiness organized by experience, exercising a guiding or dynamic influence on the person's response to all its related objects and situations. Important elements of the definition of Allport are: personal attitudes; attitudes are formed and organized by experience which is not that one comes from a negative or positive attitude. The attitude refers to our assessments of our social world of persons, groups and other objects. Attitudes are an important field of study because they affect both our perception of the world and our behaviour. The use of word attitude is based on what somebody is saying or on what someone is doing and is visible. This means that the way you speak and the activities associated to the object of attitude can see someone's attitude to something. Three components of behavior are present. According to Cherry (2018) attitudes sometimes refer to the components as $\mathrm{CABs}$ and $\mathrm{ABC}$ attitudes, cognitive components (thinking and beliefs about the topic), affective components (the feeling of the object, persons, problems or events) (how the attitude influences your behavior).

\subsection{Minimum Competency Assessment/ Asesmen Kompetensi Minimum (AKM)}

The Minister of Education and Culture has launched a new movement, namely replaced the National Examination to National Assessment. The national assessment that will be implemented is divided into 3 important parts, namely Minimum Competency Assesment, Character Survey and Learning Environment Survey (Widianti \& Hidayati, 2021). According to Nadiem Makarim, later students will face Minimum Competency Assesment and are required to be able to reason critically in working on different problems as in previous years. Minimum Competency Assesment is a competency that will be applied by the government to improve students' literacy and numeracy skills. This Minimum Competency Assesment will later emphasize literacy and numeracy reasoning skills based on the PISA test practice, that means it can be predicted that the types of problems in the Minimum Competency Assesment are adapted from the PISA test (Suri, 2020).

According to the Ministry of Education and Culture in "Pusat Asesmen dan Pembelajaran Badan Penelitian dan Pengembangan dan Perbukuan (2020)", the Minimum Competency Assessment is an assessment of the basic competencies needed by all students to be able to develop their own capacities and participate positively in society. Minimum Competency Assesment has a very good aim for the progress of the country, it is hoped that this Minimum Competency Assesment can improve the quality of education in Indonesia. Minimum Competency Assesment is very much needed in order to produce various sources of accurate information about various educational problems and to improve the quality of teaching and learning, which is then expected to also improve student learning outcomes. The Minimum Competency Assesment aspect is to measure students' cognitive abilities through iteration and numeration content because it is believed that these two things are essential and sustainable across classes and levels of education itself (Novita \& Herizal, 2021).

As we know that in the past the national exam was used as a determinant of graduation for students at the end of the level, but now this akm will not determine student graduation. In Minimum Competency Assesment there is also no value or score as a result of the answers given by students, this is done because the purpose of Minimum Competency Assesment is purely for learning improvement and not for graduation. Students will be measured their ability to understand, use, evaluate and reflect on various types of texts (Septiana, 2020). For graduation, it will still be submitted by the teacher.

\section{Method}

\subsection{Research Design}

The design of this research is qualitative research. In particular, a qualitative design is important according to Bradshaw, Atkinson, and Doody (2017) when the information is directly needed from people living in the under investigation phenomenon and where time and resources are small. Qualitative research involves the studied application and collection of empirical resources to describe moments and significations in the life of individuals (Alagan, Shanmugam, \& Veloo, 2020; Aldegether, 2020; Herman, Purba, Thao, \& Purba, 2020; Renz, Carrington, \& Badger, 2018; van Thao, Herman, Napitupulu, Hien, \& Pardede, 2021). Furthermore, the data are taken by using descriptive statistic method. Descriptive statistics is a method used to explain symptoms by using a statistical section. Descriptive statistics are statistics that are used in analyzing data by describing or describing something through 
numerical data (Sholikhah, 2016; van Thao., Herman, \& Tho, 2020; Purba et al, 2022). Descriptive statistics, which are also commonly known as statistics deductive, simple statistics, and descriptive statistics, are statistics level of work includes ways of gathering, arranging, or organize, process, present, and analyze numerical data, so that it can provide a regular, concise, and clear picture of a symptom, event, or condition (Husaini, 2013).

\subsection{Instrument of Data Collection}

Instrument is tools that are required to get information. The instrument in qualitative research is the researcher himself, in this case the researcher is the key instrument in his research (van Thao, Herman, Ha, Thuy and Tho, 2020; Sugiarto, 2017; Herman, van Thao and Purba, 2021). The researcher is the main instrument, while the supporting instrument is the questionnaire guide itself. The questionnaire is a data collection technique through a form containing questions submitted in writing on a person or group of people to get answers or responses and information required by researcher. According to Arikunto (2010) there is no certain standard to determine the number of items in the questionnaire, what is important is not too much so that the time used to fill in is only approximately an hour (Altoeriqi, 2020; Munte, Herman, Arifin, Nugroho, \& Fitriani, 2021; Ge, 2021; Herman, Murni, Sibarani and Saragih, 2019; Romera, Prados, Vicent, \& Henarejos, 2020). There are 12 statements contained in the questionnaire that would be distributed via Google Form. The statements that contained in the questionnaire were adjusted to the attitude components (cognitive, affective and behavior).

\subsection{Technique of Data Collection}

Statements contained in the questionnaire that would be distributed via Google form. The distribution of questionnaires via Google form because of the Covid-19 which made it impossible for the researcher to conduct face-to-face research with participants. The steps in collecting data in this research are as follows:

1) The researcher prepares the questionnaires in the Google Form and then share the link with participants.

2) Before filling out the questionnaire, participants are required to fill in the name.

3) Then, participants start fill out a questionnaire and they are given 45 minutes to send answers after the link is shared.

4) They are asked to click one answer of 5 options.

5) After teacher complete the questionnaire, the researcher collects all data to be analysed.

\subsection{Technique of Data Analysis}

To find out teachers' attitudes towards Minimum Competency Assesment in this research, the researchers used a Likert scale. The original Likert scale is a number of statements (items) which are available for a real or hypothesis studied. Participants must show agreement with the above statement on a metric scale (from strongly disagreeing to strong agreement) (Joshi, 2015). Furthermore, according to Agung (2020). the Likert scale is a form of scale that is used to collect data to find out or measure qualitative data. The Likert's scale is divided into five options with two kinds of statements, positive and negative. The table below is a category on the Likert scale which can be seen as follows.

Table 1. The Category of Likert Scale

\begin{tabular}{lll}
\hline Score of Positive Statements & Category of Attitude & Score of Negative Statements \\
\hline 5 & Strongly Agree (SA) & 1 \\
4 & Agree (A) & 2 \\
3 & Neutral (N) & 3 \\
2 & Disagree (DA) & 4 \\
1 & Strongly Disagree (SDA) & 5 \\
\hline
\end{tabular}

Source: Pranatawijaya et al (2019).

After collecting data from respondents, the researchers classified the amount according to the attitude category as in the table above. The researchers used formula based on the degree of attitude from Likert to find out the maximum and minimum score use the formula:

Maximum score $=$ number of respondents $\times$ highest score (5)

Minimum score $=$ number of respondents $\times$ lowest score $(1)$ 
Then, to find the index in percent form, the researcher used the following formula:

$$
P=\frac{F}{N} \times 100 \%
$$

Where:

$$
\begin{array}{ll}
\mathrm{P} & =\text { Percentage } \\
\mathrm{F} & =\text { Frequency } \\
\mathrm{N} & =\text { Total number of teachers }
\end{array}
$$

After getting the data in percent, the research analysed it by using the formula as follow:

$$
\bar{X}=\frac{\sum X}{N}
$$

Where:

$$
\begin{array}{ll}
\bar{X} & =\text { Mean Score } \\
\sum \mathrm{x} & =\text { The sum of all the scores } \\
\mathrm{N} & =\text { The number of teachers }
\end{array}
$$

\section{Result and Discussions}

\subsection{Result}

This research aims to determine teachers' attitude towards Minimum Competency Assesment in 2021. This research was conducted using a questionnaire as a research instrument that was distributed to the teachers via Google Form. This research was conducted at SMA Sultan Agung Pematangsiantar for two days starting from April 30, 2021- May 3, 2021. Participants in this study were the teachers at SMA Sultan Agung Pematangsiantar. Teachers who were participants in this study taught a variety of different subjects with undergraduate and master education backgrounds who had more than 5 years of teaching experience.

The researcher used a questionnaire instrument consisting of components of attitude that cannot be separated from each other, namely cognitive, affective and behavioral components. The questionnaire given consists of 12 items. Each component has 4 question items. Overall, the results of the research on teachers' attitudes towards Minimum Competency Assesment obtained a maximum score of 60 and a minimum score of 12 .

The results of the analysis of data collected through questionnaires are presented in the following tables.

\section{The national examination will be replaced by the National Assessment starting in 2021}

Table 2. The National Examination Will Be Replaced by the National Assessment Starting in 2021

\begin{tabular}{llll}
\hline No. & Responses & Frequency & Percentage \\
\hline 1. & Strongly Agree (SA) & 4 & $10.8 \%$ \\
2. & Agree (A) & 15 & $40.5 \%$ \\
3. & Neutral (N) & 14 & $37.8 \%$ \\
4. & Disagree (DA) & 4 & $10.8 \%$ \\
5. & Strongly Disagree (SDA) & - & - \\
6. & Total & 37 & $100 \%$ \\
\hline
\end{tabular}

Based on the results above, it can be concluded that more teachers agree with the change from National Examination to National Assessments. The number of teachers who were included in the group agreeing to this decision was 19 $(51 \%)$, this result is in stark contrast to the teachers who disagreed were $4(10.8 \%)$. Thus the teachers actually support these changes. 
Table 3. AKM is One of the "Freedom of Learning" Programs That Exists to Help Students Achieve a Learning Process That Frees Students to Be More Active

\begin{tabular}{llll}
\hline No. & Responses & Frequency & Percentage \\
\hline 1. & Strongly Agree (SA) & 6 & $16.2 \%$ \\
2. & Agree (A) & 24 & $64.9 \%$ \\
3. & Neutral (N) & 7 & $18.9 \%$ \\
4. & Disagree (DA) & - & - \\
5. & Strongly Disagree (SDA) & - & - \\
6. & Total & 37 & $100 \%$ \\
\hline
\end{tabular}

2. AKM is one of the "Freedom of Learning" programs that exists to help students achieve a learning process that frees students to be more active

The table above shows that almost all teachers agree with this statement. There were 30 groups of teachers who agreed $(81.1 \%)$ and none who disagreed $(0 \%)$ but only $7(18.9 \%)$ were in the middle of a position. With these results, it means that most teachers have realized that the Freedom of Learning program is what students need today to be more active.

3. AKM focuses on literacy and numeracy, so that other learning becomes less important

Table 4. AKM Focuses on Literacy and Numeracy, So That Other Learning Becomes Less Important

\begin{tabular}{llll}
\hline No. & Responses & Frequency & Percentage \\
\hline 1. & Strongly Agree (SA) & 2 & $5.4 \%$ \\
2. & Agree (A) & 5 & $13.5 \%$ \\
3. & Neutral (N) & 12 & $32.4 \%$ \\
4. & Disagree (DA) & 14 & $37.8 \%$ \\
5. & Strongly Disagree (SDA) & 4 & $10.8 \%$ \\
6. & Total & 37 & $100 \%$ \\
\hline
\end{tabular}

The percentage table above shows the fact that many teachers disagree with this statement, this can be seen from the number of teachers who choose to disagree is 18 (48.6), this result is still more than teachers who choose to agree, namely $7(18.9 \%)$. With these results, we can conclude that teachers are fully aware that AKM does not make other subjects less important, but AKM which consists of literacy and numeracy is the initial foundation for mastering other subjects.

4. The Government Provides Technical Guidance Which is Contained iin the AKM Series Teacher Learning Program

Table 5. The Government Provides Technical Guidance Which is Contained iin the AKM Series Teacher Learning Program

\begin{tabular}{llll}
\hline No. & Responses & Frequency & Percentage \\
\hline 1. & Strongly Agree (SA) & 4 & $10.8 \%$ \\
2. & Agree (A) & 26 & $70.3 \%$ \\
3. & Neutral (N) & 6 & $16.2 \%$ \\
4. & Disagree (DA) & - & - \\
5. & Strongly Disagree (SDA) & 1 & $2.7 \%$ \\
6. & Total & 37 & $100 \%$ \\
\hline
\end{tabular}

The results of the table analysis above illustrate that 30 teachers with a percentage of $81.1 \%$ agree with the technical guidance contained in the AKM, while only 1 (2.7\%) disagree. The teachers' decision to choose to agree means that there are still many teachers who feel that AKM is not an easy thing so that technical guidance is needed to be able to do it well. Technical guidance will really help teachers before facing akm in 2021. 


\section{I feel happy because AKM does not only involve students but also teachers and school principals}

Table 6. I Feel Happy Because AKM Does Not Only Involve Students But Also Teachers and School Principals

\begin{tabular}{llll}
\hline No. & Responses & Frequency & Percentage \\
\hline 1. & Strongly Agree (SA) & 7 & $18.9 \%$ \\
2. & Agree (A) & 27 & $73 \%$ \\
3. & Neutral (N) & 3 & $8.1 \%$ \\
4. & Disagree (DA) & - & - \\
5. & Strongly Disagree (SDA) & - & - \\
6. & Total & 37 & $100 \%$ \\
\hline
\end{tabular}

The percentage table above shows that the number of teachers who feel happy with the involvement of teachers and school principals is 34 (91.9\%). Then, the table above also shows that no teacher chose to disagree. From these results it can be concluded that teachers are happy to be involved in the implementation of AKM. Teachers have fully realized that the participation of teachers and school principals can provide a picture of the actual condition of the school in accordance with the objectives of the AKM.

6. I feel happy because the forms of questions in AKM are very varied and are of the hots type

Table 7. I Feel Happy Because the Forms of Questions in AKM Are Very Varied and Are of the Hots Type

\begin{tabular}{llll}
\hline No. & Responses & Frequency & Percentage \\
\hline 1. & Strongly Agree (SA) & 3 & $8.1 \%$ \\
2. & Agree (A) & 26 & $70.3 \%$ \\
3. & Neutral (N) & 8 & $21.6 \%$ \\
4. & Disagree (DA) & - & - \\
5. & Strongly Disagree (SDA) & - & - \\
6. & Total & 37 & $100 \%$ \\
\hline
\end{tabular}

The data in the table shows that the teachers who agree with the statement are 29 (78.4\%) and none of them choose to disagree. Teachers are happy with the variety of HOTs questions contained in the AKM, different from the National Examination, the questions contained in the AKM will vary so that they are expected to be able to improve students' higher order thinking skills.

7. I feel happy because the government has provided the AKM series teacher learning program to answer teachers' anxiety about changing the national examination to $A K M$

Table 8. I Feel Happy Because the Government Has Provided the AKM Series Teacher Learning Program to Answer Teachers' Anxiety about Changing the National Examination to AKM

\begin{tabular}{llll}
\hline No. & Responses & Frequency & Percentage \\
\hline 1. & Strongly Agree (SA) & 3 & $8.1 \%$ \\
2. & Agree (A) & 26 & $70.3 \%$ \\
3. & Neutral (N) & 8 & $21.6 \%$ \\
4. & Disagree (DA) & - & - \\
5. & Strongly Disagree (SDA) & - & - \\
6. & Total & 37 & $100 \%$ \\
\hline
\end{tabular}

The percentage table above shows that the teacher who chose to agree to the above statement was 29 (78.4\%) but no one chose to disagree. With these results it can be concluded that teachers are happy with the program, this makes teachers not need to be afraid to face AKM which is different from the National Examination. 
8. As a teacher, I feel happy with the AKM series of teacher learning program because I can collaborate with other teachers

Table 9. As a Teacher, I Feel Happy with the AKM Series of Teacher Learning Program Because I Can Collaborate with Other Teachers

\begin{tabular}{llll}
\hline No. & Responses & Frequency & Percentage \\
\hline 1. & Strongly Agree (SA) & 4 & $10.8 \%$ \\
2. & Agree (A) & 26 & $70.3 \%$ \\
3. & Neutral (N) & 7 & $18.9 \%$ \\
4. & Disagree (DA) & - & - \\
5. & Strongly Disagree (SDA) & - & - \\
6. & Total & 37 & $100 \%$ \\
\hline
\end{tabular}

The percentage table above shows that the number of teachers who are happy with the AKM Series of Teacher Learning Program is $30(81.1 \%)$. Then, the table above also shows that no teacher chose to disagree. From these results it can be concluded that teachers are happy with the AKM Series of Teacher Learning Program. Teachers have fully realized that to be able to deal with AKM well, cooperation between teachers is needed to exchange ideas and thoughts.

9. I am very ready to be one of the teachers who will face national assessment this year

Table 10. I Am Very Ready To Be One of the Teachers Who Will Face National Assessment This Year

\begin{tabular}{llll}
\hline No. & Responses & Frequency & Percentage \\
\hline 1. & Strongly Agree (SA) & 1 & $2.7 \%$ \\
2. & Agree (A) & 23 & $62.2 \%$ \\
3. & Neutral (N) & 13 & $35.1 \%$ \\
4. & Disagree (DA) & - & - \\
5. & Strongly Disagree (SDA) & - & - \\
6. & Total & 37 & $100 \%$ \\
\hline
\end{tabular}

From the table above, it can be seen that the number of teachers who feel ready to take part in the national assessment is $24(64.9 \%)$. There are no teachers who choose to disagree, it can be concluded that almost all teachers are ready to face the national assessment. To be able to take part in the national assessment, teachers are required to know and master various procedures as a capital so as not to get confused when dealing with them.

10. I am very enthusiastic about participating in the AKM series of teacher learning program

Table 11. I Am Very Enthusiastic about Participating in the AKM Series of Teacher Learning Program

\begin{tabular}{llll}
\hline No. & Responses & Frequency & Percentage \\
\hline 1. & Strongly Agree (SA) & - & - \\
2. & Agree (A) & 18 & $48.6 \%$ \\
3. & Neutral (N) & 19 & $51.4 \%$ \\
4. & Disagree (DA) & - & - \\
5. & Strongly Disagree (SDA) & - & - \\
6. & Total & 37 & $100 \%$ \\
\hline
\end{tabular}

The table above shows that there are only two responses chosen by the teacher for the above statement, namely agree and disagree. In the above statement, the number of teachers who chose to agree was 18 (48.6\%). Meanwhile, the number of teachers who chose to be neutral was 19 (51.4\%). From the above statement, it can be concluded that only half of the total teachers have high enthusiasm for participating in the AKM Series of Teacher Learning Program. In fact, from item number 7, almost all teachers were happy with the program but unfortunately it was not in line with 
enthusiasm to participate in it.

11. I will advise fellow teachers who have not participated in the AKM series of teacher learning program to join them immediately

Table 12. I Will Advise Fellow Teachers Who Have not Participated in the AKM Series of Teacher Learning Program to Join Them Immediately

\begin{tabular}{llll}
\hline No. & Responses & Frequency & Percentage \\
\hline 1. & Strongly Agree (SA) & - & - \\
2. & Agree (A) & 24 & $64.9 \%$ \\
3. & Neutral (N) & 13 & $35.1 \%$ \\
4. & Disagree (DA) & - & - \\
5. & Strongly Disagree (SDA) & - & - \\
6. & Total & 37 & $100 \%$ \\
\hline
\end{tabular}

The data in the table above illustrates that teachers who choose to agree are more than those who choose neutral. 24 $(64.9 \%)$ teachers have chosen to agree to provide advice to teachers who have not participated in the AKM Series of Teacher Learning Program to participate immediately. The table above does not show any rejection, which means that no teacher chose to disagree. The AKM Series of Teacher Learning Program has a big role in helping teachers to be better prepared for this year's national assessment.

12. I will look for examples of technical problems for the implementation of AKM on the internet.

Table 13. I Will Look for Examples of Technical Problems for the Implementation of AKM on the Internet

\begin{tabular}{llll}
\hline No. & Responses & Frequency & Percentage \\
\hline 1. & Strongly Agree (SA) & - & - \\
2. & Agree (A) & 18 & $48.6 \%$ \\
3. & Neutral (N) & 18 & $48.6 \%$ \\
4. & Disagree (DA) & 1 & $2.7 \%$ \\
5. & Strongly Disagree (SDA) & - & - \\
6. & Total & 37 & $100 \%$ \\
\hline
\end{tabular}

Based on the results above, it can be concluded that more teachers agree to look for the questions themselves in implementing the AKM. The number of teachers who were included in the group agreed on the statement was 18 $(48.6 \%)$, this result was in stark contrast to the teachers who disagreed, namely $1(2.7 \%)$. Thus the teachers actually have a high desire to have knowledge about AKM. With the many references to AKM questions on the internet, it can help teachers to continue to practice facing AKM.

The percentage results of each item have been obtained, but these results do not show the attitudes that teachers have towards Minimum Competency Assessment. The maximum score in this study is 60 and the minimum score is 12 . The interval used to determine the student's attitude category is 10 . So the intervals used in this study are grouped in the following table.

Table 14. Intervals and Percentage Results

\begin{tabular}{lc}
\hline Category of Attitude & Score \\
\hline Very Positive & $53-62$ \\
Positive & $43-52$ \\
Neutral & $33-42$ \\
Negative & $23-32$ \\
Very Negative & $12-21$ \\
\hline
\end{tabular}

To find out teachers' attitudes towards Minimum Competency Assessment, a calculation is needed to find out the mean score obtained. Of the 49 students, none of them had a maximum score of 60 and none had the lowest score of 12. In this study, the highest score obtained was 52 and the lowest score was 34 . The total score found by the 
researcher was 1.586. After getting the total score, it can be divided by the number of teachers with the following calculations.

$$
\begin{gathered}
\bar{X}=\frac{\sum X}{N} \\
\bar{X}=\frac{1.586}{37} \\
\bar{X}=44
\end{gathered}
$$

Based on the above calculations, the results of teachers' attitudes are 44. These results indicate that students have a positive attitude towards Minimum Competency Assessment. It is very important to have a positive attitude towards Minimum Competency Assessment. By having a positive attitude, it is hoped that students will be more motivated to better understand Minimum Competency Assessment, especially in improving literacy and numeration skills so that they are able to survive in 21 st century learning.

\section{Discussions}

Attitude consists of components of attitude that complement one another. Attitudes are habits that are formed based on knowledge, experience and even the environment. In this research, teachers' attitudes towards Minimum Competency Assessment were also inseparable from the attitude components that were presented in the questionnaires distributed by teachers. Attitude components consisting of cognitive, affective and behavior components will determine what attitudes teachers have.

Cognitive in this research namely components related to knowledge, views, and beliefs in objects, in this study aimed at and directed at teachers' knowledge of Minimum Competency Assessment which will be implemented starting this year as a substitute for the National Examination. The cognitive components contained in the questionnaire are listed in numbers 1,2,3 and 4. The cognitive components contain teachers' perceptual abilities towards the object of attitude in responding by assessing good or bad attitude objects that involve thinking and reasoning. Cognitive component in this research showed a positive attitude. This can be seen from the responses of teachers who prefer more agreeable answers on cognitive items. It can be interpreted that teachers have a fairly good knowledge of Minimum Competency Assessment.

The affective component is a feeling of pleasure or displeasure with something which is an individual tendency to be attracted to an object or like an object, the individual has not done any activity or something that is of interest to him. This occurs when the individual is interested in something because it is in accordance with the need or feels that what will be felt is meaningful to him. The affective component involves feelings of pleasure or displeasure. In this study, the affective component is found in items number 5,6,7 and 8. Affectively, teachers also show a positive attitude, this can be seen from the more student responses and tend to choose answers to agree even though there are those who feel unhappy. Overall, it means that teachers are happy with the change from the national exam to the national assessment or Minimum Competency Assessment. The joy of Minimum Competency Assessment is related to teachers' knowledge of Minimum Competency Assessment itself, this also proves that the affective component cannot be separated from the cognitive component.

The behavior component in this study is a component of behavior, namely a component related to the tendency of individuals to act on the object of attitude. This component shows the size of the tendency to act on the object of attitude. The conative component is a component of the will, namely the manifestation of cognitive and effective components into something that stimulates enthusiasm, concentration and consistency of actions or behavior. Someone who cognitively and affectively has a positive attitude towards something will definitely manifest it in positive behavior. In this study, a questionnaire with a behavior component was included in items number 9,10,11 and 12. Overall teachers also had quite positive behaviors. In this research, teachers tend to want to be one of the Minimum Competency Assessment participants and want to practice finding references and training on Minimum Competency Assessment. The positive attitude shown by teachers in the behavior component cannot be separated from the role of the cognitive and affective components. That is why the three components in attitude are inseparable and have an influence on one another.

The positive results obtained in this research are in line with the research conducted by Novita and Herizal (2021) with the title "National Assessment: Knowledge and Perception of Teacher Candidates". As we know, that actually the Minimum Competency Assessment will not only be followed by students, but the Minimum Competency 
Assessment will also be followed by teachers and even school principals. The study found that teachers had a positive perception of $54 \%$. This means that more than some teachers understand and give a positive perception of the Minimum Competency Assessment. When the teachers have a good understanding of the Minimum Competency Assessment, the easier it will be for the teachers to motivate students and provide explanations for students, especially for students who do not know the Minimum Competency Assessment at all. This research is also in line with the results of research with title "Public Opinion about the National Assessment as Substitute for the National Exam". The research aims to determine the understanding of the general public and intellectuals about the national assessment program initiated by the Ministry of Education and Culture. Based on the results of research conducted by researcher, as many as $91.9 \%$ of people agree with the existence of a national assessment as a substitute for the national exam in 2021. This is because the national assessment will be able to help Indonesian education achieve maximum results, through reading and motivating students to analyze symbols -number symbols to be practiced in everyday life. This study and previous research both discuss national assessment and are included in opinion research. however, none of the two studies specifically discussed the Minimum Competency Assessment, and in this study the participants were students who would face the Minimum Competency Assessment directly.

There are many things that can be done in order to increase knowledge about Minimum Competency Assessment. One way that teachers can do it is by practicing and searching for Minimum Competency Assessment reference questions on the internet and following AKM Series of Teacher Learning Program. Not only that, teachers can always read the latest information about Minimum Competency Assessment which will make them more knowledgeable. After having sufficient knowledge, over time their attitudes in the affective component also change, so they can become wiser in determining their liking and liking for Minimum Competency Assessment. Then, after they have positive cognitive and affective attitudes, it will be easier to manifest it in positive behavior as well.

\section{Conclusions}

The teachers' attitudes towards Minimum Competency Assessment are positive attitude with a total of 44 points. The results of the analysis of each component (cognitive, affective and behavior) also showed a positive attitude. This can be seen from the tendency of students to choose responses to agree on positive items and to choose neutral responses and to disagree on negative items. It is very important for teachers to have a positive attitude towards Minimum Competency Assessment, this is because teachers will be the objects who will do Minimum Competency Assessment. Having a positive attitude in one attitude will make it easier to have a positive attitude in other components as well. By having a positive attitude, it is hoped that teachers can do it well so that the mapping of the quality of education expected by the government is in accordance with the actual facts. As a teacher, they must know about Minimum Competency Assessment in order to provide more explanation to students about Minimum Competency Assessment. When teachers and students know the Minimum Competency Assessment and its procedures, the implementation will be good and get the facts as desired for the advancement of the quality of education in Indonesia.

\section{References}

Agung. (2020). Understanding likert scale, formulas and how to calculate it. Retrieved from https://serviceacjogja.pro/skala-likert/

Alagan, T., Shanmugam, S. K. S., \& Veloo, A. (2020). Tamil primary school teachers understanding on constructing HOTS items in mathematics. Humanities and Social Sciences Letters, 8(2), 156-168. https://doi.org/10.18488/journal.73.2020.82.156.168

Aldegether, R. (2020). Predicting reflective thinking among Saudi elementary school teachers in Riyadh public schools. International Journal of Education and Practice, 8(3), 405-415.

Altoeriqi, E. A. (2020). Saudi English teachers' perception of their own pronunciation and use of teaching practices of pronunciation skills. International Journal of English Language and Literature Studies, 9(4), 276-285. https://doi.org/10.18488/journal.23.2020.94.276.285.

Allport, G. W. (1935). Attitudes. In C. M. Murchison (Ed.), Handbook of Social Psychology. Winchester, MA: Clark University Press.

Arikunto, S. (2010). Research procedure a practical approach. Jakarta: Bumi Aksara.

Bradshaw, C., Atkinson, S., \& Doody, O. (2017). Employing a qualitative description approach in health care research. SAGE Journals, 4, 233339361774228. https://doi.org/10.1177/2333393617742282 
Cherry, K. (2018). Attitudes and behavior in psychology. Retrieved from https://www.verywellmind.com/attitudes-how-they-form-change-shape-behavior-2795897?print

Dewabrata, M. (2019). PISA 2018 results officially announced, Indonesia experiences a decline in score in every field. Retrieved from https://www.zenius.net/blog/pisa-2018-2019-standar-internasional

Ge, S. (2021). Application of translation workshop to college English translation teaching. International Journal of Emerging Trends in Social Sciences, 10(1), 34-40. https://doi.org/https://doi.org/10.20448/2001.101.34.40

Herman, Murni, S. M., Sibarani, B., \& Saragih, A. (2019). Structures of Representational Metafunctions of the "Cheng Beng" Ceremony in Pematangsiantar: A Multimodal Analysis. International Journal of Innovation, Creativity and Change, 8(4), 2019. Retrieved from https://www.ijicc.net/images/vol8iss4/8403_Herman_2019_E_R.pdf

Herman, Purba, R., Thao, N. V., \& Purba, A. (2020). Using genre-based approach to overcome students' difficulties in writing. Journal of Education and E-Learning Research, 7(4), 464-470. https://doi.org/10.20448/journal.509.2020.74.464.470

Herman, van Thao, N., and Purba, N. A. (2021). Investigating Sentence Fragments in Comic Books: A Syntactic Perspective. World Journal of English Language, 11(2), 139-151. https://doi.org/10.5430/wjel.v1 1n2p139

Husaini, U. P. (2013). Introduction to statistics. Jakarta: PT. Earth Literature.

Joshi, A. (2015). Likert scale: Explored and explained. British Journal of Applied Science \& Technology, 7(4), 396-403.

Kisno, Siregar, V. M., Sirait, S., \& Winata, A. S. (2021). Dissemination of literacycloud for teachers and parents of public elementary schools in Patumbak Deli Serdang District during the covid-19 pandemic period. Educational Publications Journal of Thought, Research and Community Service in Education, 15-21.

Munte, B., Herman, Arifin, A., Nugroho, B. S., \& Fitriani, E. (2021). Online student attendance system using android. Paper presented at the Journal of Physics: Conference Series. 1933012048.

Ningsih, A. W., Shara, A. M., \& Andriani, D. (2021). Reading duration and financial literacy in vocational high school. Jurnal Education and Development, 9(1), 577-577.

Novita, N., \& Herizal, M. (2021). National assessment (AN): Knowledge and perception of prospective teachers. Journal of Social Sciences and Education, 172-179.

Perdana, N. S. (2021). Analysis of student readiness in facing minimum competency assessment. Preamble to the Journal of Education, History, and Social Sciences, 15-20.

Pranatawijaya, V. H., Widiatry, W., Priskila, R., \& Putra, P. B. A. A. (2019). Penerapan Skala Likert dan Skala Dikotomi Pada Kuesioner Online. Jurnal Sains dan Informatika, 5(2). https://doi.org/10.34128/jsi.v5i2.185

Purba, R., Sibarani, B., Murni, S. M., Saragih, A., \& Herman. (2022). Conserving the Simalungun Language Maintenance through Demographic Community: The Analysis of Taboo Words Across Times. World Journal of English Language, 12(1), 40-49. https://doi.org/10.5430/wjel.v12n1p40

Renz, S. M., Carrington, J. M., \& Badger, T. A. (2018). Two strategies for qualitative content analysis: An intramethod approach to triangulation. Qualitative Health Research, 28(5), 824-831. https://doi.org/10.1177/1049732317753586

Romera, C. G., Prados, M. A. H., Vicent, P. L., \& Henarejos, A. C. T. F. (2020). Development of social and civic competence in the classroom through art. Asian Journal of Contemporary Education, 4(2), 99-109. https://doi.org/10.18488/journal.137.2020.42.99.109

Septiana, T. W. (2020). Teachers and students, these are the components to be tested in the 2021 minimum competency assessment.

Shara, A. M., Andriani, D., Ningsih, A. W., \& Shinoda, K. (2020). Correlating reading literacy and writing literacy in junior high school Pematangsiantar. Journal of English Education, 5(2), 72-85. https://doi.org/10.31327/jee.v5i2.1249

Sholikhah, A. (2016). Descriptive statistics in qualitative research. Communications, 342-362.

Suri, F. (2020). Learning in the independent Era of learning against the metacognitive ability of learners. Paper presented at the Proceedings of the LP3M National Seminar 2.

Thomson, S. K. H. (2013). A teacher's guide to PISA reading literacy (pp. 1-54): ACER Press. 
van Thao, N., Herman, Napitupulu, E. R., Hien, N. T., \& Pardede, H. (2021). Code-switching in learning via zoom application: A study in an EFL context. Asian ESP Journal, 17(3.1), 91-111.

van Thao., N., Herman \& Tho, N. T. Q. (2020). A comparative study of words indicating 'artificial containers of water' in Vietnamese and English. International Journal of Innovation, Creativity and Change, 12(10), 328-337.

van Thao, N., Herman., Ha, T. T., Thuy, N. T. T., \& Tho, N. T. Q. (2020). Analysis of Argumentation in Nam Cao's Story 'Chi Pheo' Based on a Pragmatics Perspective. International Journal of Innovation, Creativity and Change. www.ijicc.net, Volume 12, Issue 12, 2020. Retrieved from https://www.ijicc.net/images/vol12/iss12/121288_Thao_2020_E_R.pdf

Widianti, W., \& Hidayati, N. (2021). Analysis of the mathematical literacy ability of junior high school students on triangle and quadrilateral material. Journal of Innovative Mathematics Learning, 27-38.

\section{Copyrights}

Copyright for this article is retained by the author(s), with first publication rights granted to the journal.

This is an open-access article distributed under the terms and conditions of the Creative Commons Attribution license (http://creativecommons.org/licenses/by/4.0/). 